\title{
CONTROL OF ANTHRACNOSE IN PAPAYA FRUITS BY ACETYLSALICYLIC ACID AND 1-METHYLCYCLOPROPENE
}

\section{CONTROLE DA ANTRACNOSE EM MAMÃO POR ÁCIDO ACETIL SALICÍLICO E 1-METILCICLOPROPENO}

\section{Leonardo Ferreira LOPES ${ }^{1}$; André Freire Cruz ${ }^{2}$; Mariana Coelho de SENA ${ }^{1}$; Luiz Eduardo Bassay BLUM ${ }^{3}$}

1. M.Sc., Departamento de Fitopatologia, Instituto de Ciências Biológicas, Universidade de Brasília, Brasília, DF, Brasil; 2. Ph.D., Graduate School of Life and Environmental Sciences, Kyoto Prefectural University, Kyoto, Japan; 3. Professor, Ph.D., Departamento de Fitopatologia, Instituto de Ciências Biológicas, Universidade de Brasília, Brasília, DF, Brasil, luizblum@unb.br.

\begin{abstract}
This study assessed the effect of acetylsalicylic acid (ASA) and 1-methylcyclopropene (1-MCP) to control anthracnose in papaya (cultivar Golden). Disinfested-surface fruits were inoculated with Colletotrichum gloeosporioides and then the compounds were applied. The lesion diameters and the physicalchemical properties were analyzed. Assays were carried out with ASA and 1-MCP targeting the control of anthracnose and maintenance of the fruit's physical-chemical properties. The effect of ASA (20 mM; $20 \mathrm{~min})$ on reducing lesion diameter occurred when applied before inoculation. Fruits treated with 1-MCP (300ppb) for $12 \mathrm{~h}$ showed a smaller lesion diameter than control. For the physical-chemical analysis, fruit treated with 1MCP (200; 300 ppb; 12h) maintained fruit firmness, delayed fruit ripening and fruit fresh weight loss.
\end{abstract}

KEYWORDS: Disease control. Fruit-rot. Colletotrichum. Fruit-quality. Ripeness.

\section{INTRODUCTION}

Papaya (Carica papaya L.) is a perennial fruit plant from the Caricaceae family, and it is a crucial crop in Brazil and in other tropical and subtropical regions worldwide. Inappropriate postharvest management may severely affect fruit quality and increase disease severity (JACOMINO et al., 2003), especially anthracnose, mainly caused by Colletotricchum gloeosporioides (Penz.) Penz. \& Sacc. Papaya fruits showing post-harvest anthracnose symptoms present sunken, prominent, dark brown to black lesions (DICKMAN, 1994). The control of this disease sometimes leads to other problems, since in some cases the treatments affect the ripening process, and the use of fungicides for extended periods may lead to the appearance of fungicide resistant Colletotrichum strains (GAMAGAE et al., 2003).

Acetylsalicylic acid (ASA) is a phenolic compound involved in the regulation of many processes in plant growth and development, such as the inhibition of aminocyclopropane carboxylic acid (ACC) oxidase activity, which converts ACC into ethylene (ALMONEAFY et al., 2013). ASA can also reduce the autocatalytic production of ethylene and seems to reduce ethylene production caused by stress (ABELES et al., 1997). An essential function of ASA is the activation of plant defense reactions against pathogens (HOROTAN; OANCEA, 2013). The exogenous application of ASA to inhibit ethylene production in Kiwi fruits was showed, resulting in delayed fruit ripening by interfering with ethylene biosynthesis and perception (YIN et al., 2013). Therefore, this compound might reduce postharvest papaya anthracnose.

1-Methylcyclopropane (1-MCP) is an effective ethylene blocker in many plant products, especially in climacteric fruits, such as papaya (AHMAD et al., 2013; FABI et al., 2007). This molecule competes with ethylene for its receptor site, preventing it from binding and causes no response in the plant cell. These results suggest that this compound could be useful for maintaining certain quality standards and biochemical parameters, which might extend the shelf life of apples and other fruits (BIZJAK et al., 2012). Considering all these effects of some compounds on papaya fruits during the post-harvesting stage, this study aimed to evaluate the effect of ASA and 1$\mathrm{MCP}$ on disease suppression and fruit quality.

\section{MATERIAL AND METHODS}

Colletotrichum isolation - Papaya fruits (cv. Golden; ripening stage 0-1) were purchased from CEASA-DF, Brazil. The fruits were inserted in wet chambers (plastic trays with wet paper towels inside, closed with parafilm) at room temperature $\left(20-25^{\circ} \mathrm{C}\right)$ for $24 \mathrm{~h}$. Fungal structures present in typical anthracnose lesion were aseptically transferred to medium containing $50 \%$ Potato 
Dextrose Agar (PDA) and incubated for 15 days $\left(25^{\circ} \mathrm{C}\right.$; light $12 \mathrm{~h} \mathrm{/} \mathrm{day).} \mathrm{C.} \mathrm{gloeosporioides} \mathrm{was}$ morphologically identified, and the conidia were suspended in sterilized water and then filtered through a double layer of gauze. The conidial concentration was estimated using a Neubauer plate and then adjusted $\left(10^{6}\right.$ conidia $\left.\mathrm{mL}^{-1}\right)$.

Fruit inoculation - Papaya fruits, ripening stage $0-1 \quad(<20 \%$ yellowish), obtained from CEASA-DF, Brazil, were disinfested with $10 \%$ Ethanol $(1 \mathrm{~min})$, followed by $1 \%$ sodium hypochlorite $(1 \mathrm{~min})$, and then rinsed in sterilized distilled water for $1 \mathrm{~min}$. Fruits were punctured at five equidistant points to a $2-\mathrm{mm}$ depth, and $50 \mu \mathrm{L}$ of the previously prepared conidial suspension $\left(10^{6}\right.$ conidia $\mathrm{mL}^{-1}$ ) was inoculated in the holes. After inoculation, fruits were incubated in a chamber for $24 \mathrm{~h}$ (in plastic boxes containing wet paper) at room temperature $\left(20-25^{\circ} \mathrm{C}\right)$. Sterilized water $(50 \mu \mathrm{L})$ was added to each hole in control fruits.

Effect of ASA on anthracnose - Two types of experiments were conducted. First (experiments 1 and 2), the fruits were subjected to different doses of ASA $(10,20$, and $30 \mathrm{mM})$ for three indicated times $(10,20$, and $30 \mathrm{~min}), 24 \mathrm{~h}$ before inoculation. In the second set of experiments ( 3 and 4), fruits were subjected to the same treatments $24 \mathrm{~h}$ after inoculation. These products were dissolved in a 6-L plastic box and the fruits, after inoculation, were immersed in the solution at room temperature for 20 min. The control treatments, for each experiment, followed the same procedures with the same amount of water applied, alone. Fruits after treatment were dried and stored in incubator (light $/ 12 \mathrm{~h} ; 13^{\circ} \mathrm{C}$ ) for 10 days, and during this period the diameter $(\mathrm{mm})$ of the lesion (LD) was measured daily. For each treatment five fruits were inoculated, and each assay was conducted twice. All treatments were also applied in non-inoculated fruits for reference.

Effect of 1-MCP on anthracnose - Two assays were performed, after disinfestation and fruit inoculation processes as described in experiment 1 . Fruits were packed in 120-L Styrofoam boxes (PINHEIRO et al. 2005). 1-MCP was applied using $500-\mathrm{mL}$ plastic bottles containing the product [SmartFreshTM Technology $(0.33 \%$ a.i. $)$, and water (25 mL g ${ }^{-1}$ powder)] at $60^{\circ} \mathrm{C}$. Bottles were closed with screw cap, shaken to obtain a homogenous mixture, and placed in the center of each polystyrene box. They were opened to release the gas produced by adding the product to hot water, and boxes were closed immediately after the release of the gas. Fruits were exposed to different concentrations of the gas $(0,50,100,200$, and 300 ppb) for two periods (12 and $24 \mathrm{~h})$ at $25 \pm 3^{\circ} \mathrm{C}$ and then were stored in a moist chamber, with a light photoperiod of $12 \mathrm{~h}$ at $25^{\circ} \mathrm{C}$ for 5 days, with the same procedures for $\mathrm{LD}$ measurement.

The fruit ripening stage $[0=$ totally green skin; $1=$ green skin with light yellow stripe $(<20 \%$ of skin surface); $2=$ green skin with well-defined yellow stripe $(21-40 \%$ of skin); $3=$ one or more yellow stripes $(41-60 \%$ of skin); $4=$ skin predominantly yellow (61-80\% of skin) with some green areas; $5=$ skin clearly yellow ( $>80 \%$ of skin)] was evaluated daily.

\section{Physical-chemical analysis of fruits -} Physical-chemical analysis of fruits was carried out as previously described (BLUM et al., 2007; CRUZ et al., 2015; FERRAZ et al., 2013). Briefly, this research followed these methods: (a) fresh mass loss $(\% \mathrm{FWL}): \% \mathrm{FWL}=[($ initial fresh weight - final fresh weight)/initial fresh weight $] \times 100 .(b)$ Ripening stage: Degree of ripening scale ranging from 1 to 5. (c) Firmness: Hand penetrometer (Fruit Pressure Tester, FT 327, $8 \mathrm{~mm}$ tip) using the formula: $\mathrm{P}=\mathrm{F} / \mathrm{A}$. Where, $\mathrm{P}=$ Firmness $\left(\mathrm{kg} \mathrm{cm}^{-2}\right), \mathrm{F}$ $=$ penetration force $(\mathrm{kg})$, and $\mathrm{A}=$ area of tip $\left(\mathrm{cm}^{2}\right)$. (d) $\mathrm{pH}$ : (digital $\mathrm{pH}$ meter 'Quimis' template 400M1$\mathrm{Q} / 2$ ). (e) Total soluble solids (TSS- ${ }^{\circ}$ Brix) with the portable refractometer (Hand Held refractometer 'Atago', N-1E) and adjustment of 'Brix with a correction table (IAL 2008). (g) Titratable acidity (TA): Estimated by the equation: $\mathrm{TA}=\mathrm{Vg} \times \mathrm{N} \times \mathrm{f} \times$ Eq Ac/10 $\times$ g, where: $\mathrm{Vg}=$ volume of $\mathrm{NaOH}$ used $(\mathrm{mL}) ; \mathrm{N}=$ normality of $\mathrm{NaOH}(0.01 \mathrm{~N}) ; \mathrm{f}=$ correction factor obtained for $\mathrm{NaOH}$ standardization; Eq. Ac. = Acid Equivalent (papaya $=64) ; \mathrm{g}=$ sample weight.

Experimental design - All experiments were conducted twice with five fruits per treatment. The statistical design was a randomized block with five replications in a split plot arrangement. Data were subjected to analysis of variance (Table 1), and the treatment means were compared using Fisher's LSD test $(p \leq 0.01)$. Statistical analyses of the data were performed using SigmaStat 2.0 (Jandel Corporation 1992-1995) software. 
Table 1. Statistical significance of the evaluated variables used in the analysis of variance for each trial performed with Acetylsalicylic acid (ASA) and 1-Methylcyclopropene (1-MCP).

\begin{tabular}{lllllllll} 
Trial & Assays/Products & $\mathbf{L D}^{1}$ & $\mathbf{F M L}^{2}$ & $\mathbf{M S}^{\mathbf{3}}$ & $\mathbf{F i r m}^{\mathbf{4}}$ & $\mathbf{p H}$ & $\mathbf{T S S}^{\mathbf{5}}$ & $\mathbf{T A}^{\mathbf{6}}$ \\
\hline $\mathbf{1 - 2}$ & ASA (BI) & $*$ & n.s. & n.s. & n.s. & n.s. & n.s. & n.s. \\
$\mathbf{3 - 4}$ & ASA (AI) & $*$ & n.s. & n.s. & n.s. & n.s. & $*$ & n.s. \\
$\mathbf{5 - 6}$ & 1-MCP & $*$ & $*$ & $*$ & $*$ & n.s. & n.s. & n.s. \\
\hline
\end{tabular}

${ }^{1} \mathbf{L D}=$ diameter of the lesion $(\mathrm{mm}) ;{ }^{2} \mathbf{F M L}=$ fresh mass loss; ${ }^{3} \mathbf{M S}=$ maturation stage; ${ }^{4}$ Firmness; ${ }^{5} \mathbf{T S S}=$ total soluble solids; ${ }^{6} \mathbf{T A}=$ titratable acidity; $\mathrm{BI}=$ Before inoculation of the pathogen; $\mathrm{AI}=$ After inoculation; ${ }^{*}$ F Test significant $(\mathrm{p} \leq 0.05) ;$ n.s. $=$ Not significant.

\section{RESULTS AND DISCUSSION}

The average of the two trials indicated that application of ASA $24 \mathrm{~h}$ before inoculation, at 10 $\mathrm{mM} / 10 \mathrm{~min}$ and $20 \mathrm{mM} / 20 \mathrm{~min}$, showed a reduction in LD (Figure 1A, B). However, the same application made $24 \mathrm{~h}$ after inoculation showed that only a dose of $20 \mathrm{mM} / 10$ and $20 \mathrm{~min}$ was effective (Figure $1 \mathrm{C}, \mathrm{D})$. The pre-inoculation application of
ASA may possibly promote a higher inhibition effect than application after inoculation. Qin et al. (2003) reported that salicylic acid (SA) was used to enhance biocontrol efficacy in cherries. The SA treatment induced a significant increase in polyphenoloxidase, phenyl-alanine ammonia-lyase and $\beta$-1,3-glucanase activity in cherry fruit, thereby increasing the biochemical protection response.
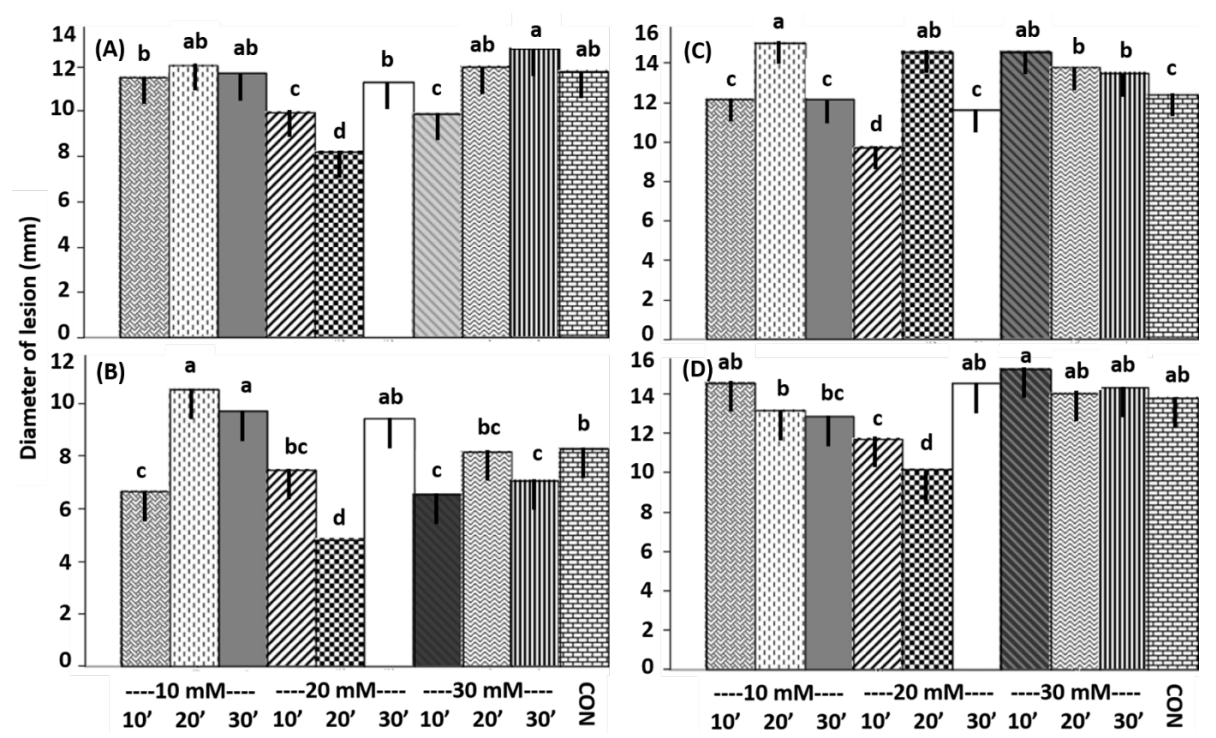

Figure 1. Diameter ( $\mathrm{mm}$ ) of the anthracnose lesion in papaya fruits ('Golden') treated with Acetyl Salicylic Acid (ASA - 10, 20, $30 \mathrm{mM}$ ) at 3 exposure times (10, 20 and $30 \mathrm{~min})$ before (A-B; trials 1 and 2$)$ and after (C-D; trials 3 and 4) inoculation with Colletotrichum gloeosporioides. CON = control without ASA. Bars with the same letters are not significantly different [Fisher test LSD (Least Significant Difference $=$ slim black bar); $\mathrm{p} \leq 0.01]$.

Fruit treated with MCP-1 for $24 \mathrm{~h}$ had no reduction in disease severity for any assay. Only the fruits exposed to $300 \mathrm{ppb}$ for $12 \mathrm{~h}$ showed a reduction in LD compared to the control (Figure 2A, B). Similar results were found by Pesis et al. (2002), who observed that the application of 100 to $300 \mathrm{~nL}$ $\mathrm{L}^{-1}$ of 1-MCP in Hass avocado significantly reduced the development of rot spots. This biochemical effect in avocados that occurs during fruit ripening might make the treatment more applicable to other fruits too. In apples of the Gala variety, treatment with $635 \mathrm{~nL} \mathrm{~L}^{-1}$ of this product could reduce the percentage of post-harvest rot spots in fruits stored for 15 and 45 days at $20^{\circ} \mathrm{C}$. Similar reductions in fruits stored for 6 months under a controlled atmosphere were observed, and in Gala and Fuji apples after a 3- and 6-month storage (Gala) at $0{ }^{\circ} \mathrm{C}$. 'Canino' apricots had fewer rotting fruit when treated with a concentration of $1000 \mathrm{~nL} \mathrm{~L}^{-1}$ (DONG et al., 2002). 


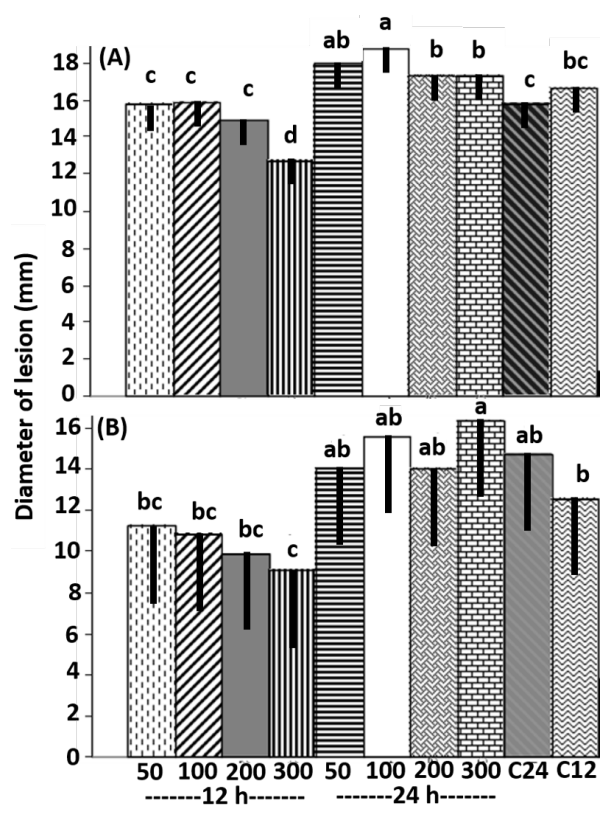

Figure 2. Diameter (mm) of the anthracnose lesion in papaya fruits ('Golden') inoculated with Colletotrichum gloeosporioides and treated with 1-MCP at different concentrations (0, 50, 100, 200, $300 \mathrm{ppb})$ for 12 or 24h. Trial 5 (A) and trial 6 (B). C12 and C24 are controls without 1-MCP. Bars with the same letters are not significantly different [Fisher test LSD (Least Significant Difference = slim black bar); $\mathrm{p} \leq 0.01]$.

Other treatments associated with those reported in this research could also reduce anthracnose in fruits, especially hot water applied on mango (YIMYONG et al., 2011), banana (MIRSHEKARI et al., 2012), apple, peach, and nectarine (MAHAJAN et al., 2014). In papaya, immersion in hot water $\left(49^{\circ} \mathrm{C} / 20 \mathrm{~min}\right)$ has been the main treatment for post-harvest rot control since 1964, when it started to be applied on an industrial scale (COUEY; ALVAREZ, 1984). However, in the case of anthracnose, some studies have shown that hot water treatment is not fully effective when used alone (MIRSHEKARI et al., 2012; YIMYONG et al., 2011). These authors confirmed that the effect of $\mathrm{Ca}$ on texture can be attributed to a lower activity of the enzyme pectin methylesterase, which led to a lower percentage of pectin solubilization in fruits treated with $\mathrm{CaCl}_{2}$

Fruits treated with 1-MCP had a higher firmness compared to untreated fruits. Similarly, in experiments with peach fruit of the cultivar Diamond, Oliveira et al. (2005) found that those treated with 1-MCP lost less firmness throughout the storage period at room temperature. When analyzing the delayed ripening of various fruits in response to the application of 1-MCP, Manenoi et al. (2007) found that papaya presented good results. This might occur due to a longer incubation period after the application of 1-MCP, demonstrating that the concentration of ethylene receptors in papaya is enough to resume the normal ripening process.
There was no improvement in the treatments with ASA (Figure 3) for the Total soluble solids ('Brix) in papaya fruits' characteristics evaluated in two experiments (Table 1). The application of ASA to control the anthracnose has been reported (ZAINURI et al., 2001). These authors explained that the control of anthracnose by ASA in mango fruits could be attributed to the effects of acid on inhibiting fruit ripening. The ripening delay might be due to some anti-ethylene effect, as observed in bananas (SRIVASTAVA; DWIVEDI, 2000) and cannot be linked to the increasing antifungal activity in fruit peels. Similarly, Zhang et al. (2003) demonstrated that treatment of kiwi with ASA resulted in higher levels of salicylic acid, delaying the effects of lipoxygenase activity and the production of superoxide free radicals. Mandal et al. (2017) showed that SA (2.5 to $3.0 \mathrm{mM})$ may be the effective post-harvest treatment to extend shelf life while maintaining the physical-chemical qualities of papaya (cv. Red Lady) during storage at room temperature. Also, these authors reported that SAtreated fruits showed a reduction in fruit decay, and delayed ripening and physical-chemical changes in papaya may be due to delayed climacteric respiration peak and reduced ethylene production. 


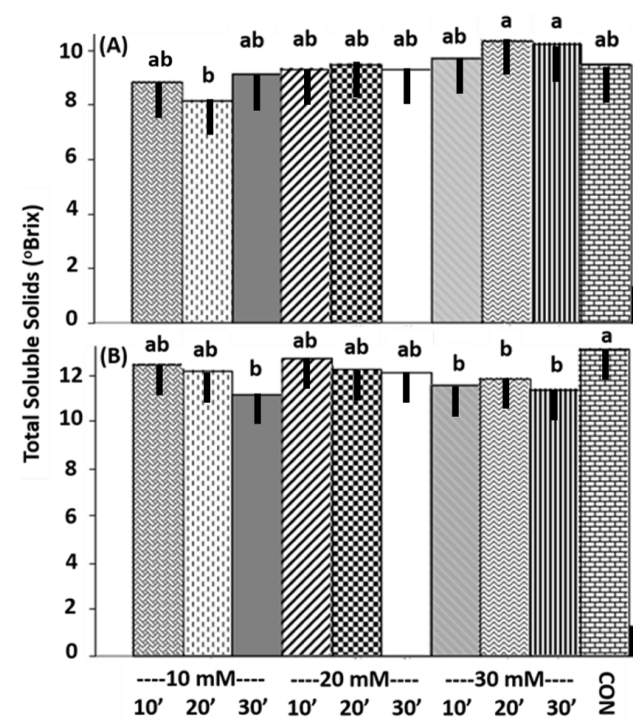

Figure 3. Total soluble solids ( ${ }^{\circ}$ Brix) in papaya fruits ('Golden') treated with Acetyl Salicylic Acid (10, 20, 30 $\mathrm{mM})$ at 3 exposure times (10, 20 and $30 \mathrm{~min})$ after inoculation with Colletotrichum gloeosporioides (A and B; trials 3 and 4). CON = control without ASA. Bars with the same letters are not significantly different [Fisher test LSD (Least Significant Difference $=\operatorname{slim}$ black bar); $\mathrm{p} \leq 0.01$ ].

ASA can also suppress the activities of ACC synthase and oxidase, and the biosynthesis of ethylene, delaying the climacteric peak, ripening, and fruit senescence. According to these authors, these mechanisms suggest the possibility of using ASA to regulate ethylene formation and prevent the deterioration of cell membranes and tissue senescence. These phenomena are usually induced by superoxide free radicals, due to their function in enzymes that are involved in the synthesis of hormones.

Promyou and Supapvanich (2016) found that papaya fruit immersed in salicylic acid (SA; 2
$\mathrm{mM}$ ) produced a delay in loss of firmness and enhanced antioxidant capacity and total phenols. This study showed that SA immersion maintains post-harvest quality and enhances active compounds of the papaya during storage. Application of SA inhibits ethylene biosynthesis or action and thereby improved the quality of post-harvest (VALERO et al. 2011). Post-harvest treatments of sweet cherry with compounds such as SA, ASA or oxalic acid resulted in extended storability (VALERO et al. 2011).

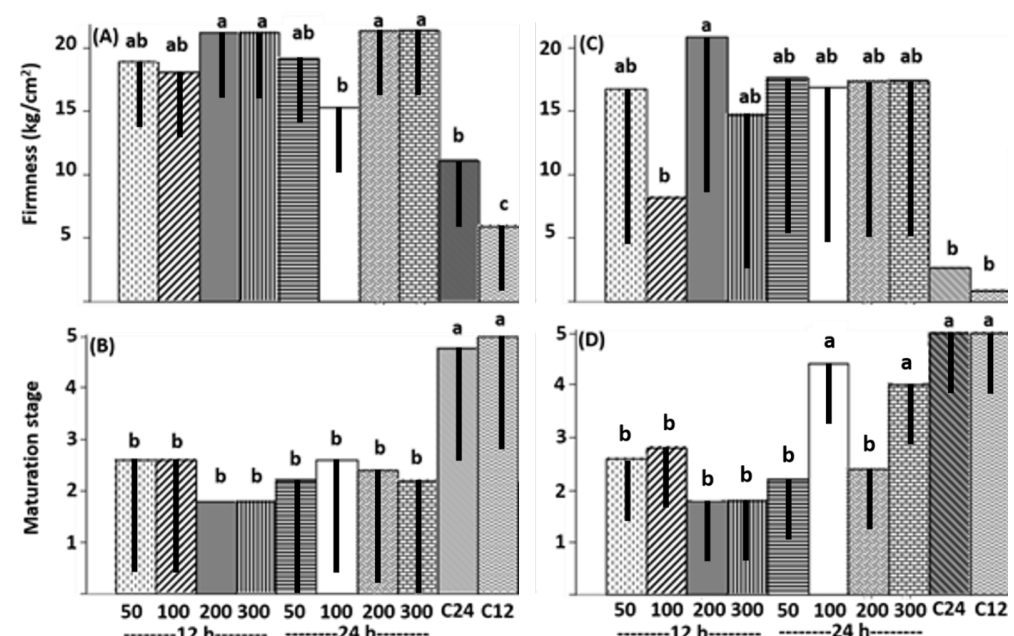

Figure 4. Firmness $\left(\mathrm{kg} \mathrm{cm}^{-2}\right)$ and maturation stage [0 (green) to 5 ( $>75 \%$ yellow)] of papaya ('Golden'), submitted to applications of 1-MCP at different concentrations $(0,50,100,200,300 \mathrm{ppb})$ for 12 or 24h. Trial 5, pathogen inoculated (A-B) and non-inoculated fruits (C-D). C12 and C24 are controls without 1-MCP. Bars with the same letters are not significantly different [Fisher test LSD (Least Significant Difference $=$ slim black bar); $\mathrm{p} \leq 0.01]$. 
The fruit's firmness within the group exposed to 1-MCP $12 \mathrm{~h}$ was strongly affected by this compound, whereas for those exposed for $24 \mathrm{~h}$ only the $300 \mathrm{ppb}$ dose was effective in increasing the firmness (Figure 4A, C). Fruits exposed to any concentration of 1-MCP at any period showed a lower maturation stage in relation to the controls, and this parameter in all treatments was significantly lower than the untreated control (Figure 4B, D). In another trial, the maturation stage could be reduced with $300 \mathrm{ppb}$ of 1-MCP within $12 \mathrm{~h}$ compared to the control (Figure 5B).

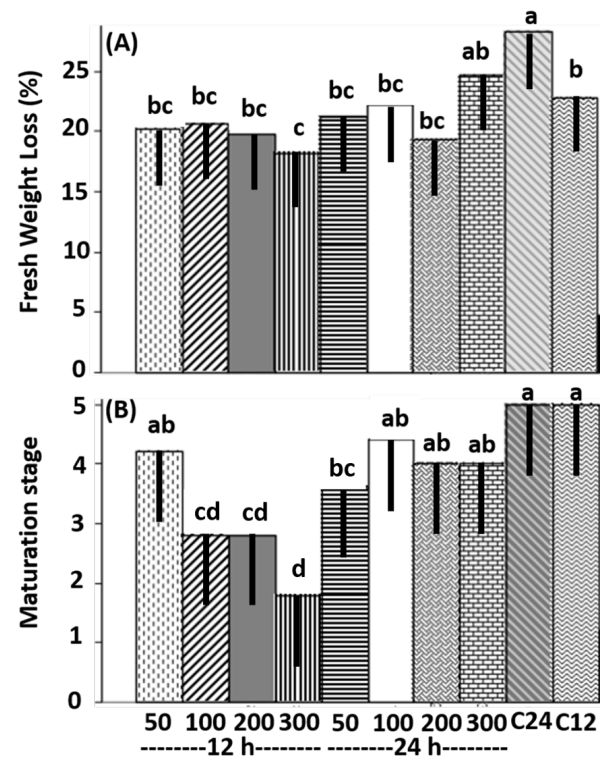

Figure 5. Papaya fruit fresh weight loss (\%) (A) and maturation stage $[0$ (green) to $5(>75 \%$ yellow) $(\mathbf{B})$ in papaya fruits ('Golden') inoculated with Colletotrichum gloeosporioides and treated with 1-MCP at 0 , $50,100,200$ and $300 \mathrm{ppb}$ for 12 or $24 \mathrm{~h}$ (Trail 6). Bars with the same letters are not significantly different [Fisher test LSD (Least Significant Difference $=$ slim black bar); $\mathrm{p} \leq 0.01$ ].

The effect of 1-MCP on delaying senescence may be attributed to its ability to inhibit ethylene synthesis (SISLER; SEREK, 1997), leading to delayed senescence and maintenance of fruit quality, such as delayed softening or a delay in ripening and other changes which may lead to an increase in the storage life of the fruit (BLANKENSHIP; DOLE, 2003). Asmar et al. (2010) submitted papaya fruits (Sunrise Solo) to 1$\operatorname{MCP}\left(270 \mathrm{~nL} \mathrm{~L}^{-1}\right)$ for $0,12,18$ and $24 \mathrm{~h}$, and then stored them $\left(22 \pm 2{ }^{\circ} \mathrm{C}\right.$; RH $\left.77 \% \pm 2 \%\right)$ for $8 \mathrm{~d}$. Ohashi et al. (2016) found that the use of 1-MCP for fruits increased 'Solo' papaya shelf-life, because of the ability to inhibit ethylene action in tissues, delaying fruit ripening. The 1-MCP-treated fruits showed increased firmness, lower contents of soluble pectin and less activity of the PME enzyme, demonstrating that 1-MCP was effective in delaying the softening of the fruits. The FWL within $12 \mathrm{~h}$ of 1-MCP application presented a significant reduction at $300 \mathrm{ppb}$, but after $24 \mathrm{~h}$ this reduction was reached at $200 \mathrm{ppb}$ (Figure 5A). The use of ethylene synthesis blockers, such as 1-MCP, has been researched and is efficient in slowing fruit ripening and reducing the intensity of anthracnose infection during storage (CAO \& ZHENG, 2010). The association of control methods is needed to reduce the extent of fruit rots, and to reduce the number of rotten fruits (MAHAJAN et al., 2014). Papaya treatments here presented in combination with phosphites (AMARAL et al., 2017), hot water (AYÓN-REYNA et al., 2017) and radiation (MAHAJAN et al., 2014) might exclude disease, which is an important requirement for papaya fruit commercialization (DEMARTELAERE et al, 2017).

\section{CONCLUSIONS}

ASA (20 mM / $20 \mathrm{~min})$ reduced lesion diameter when applied before inoculation.

Fruits treated with 1-MCP (300 ppb / 12h) showed a smaller lesion diameter.

Fruit treated with 1-MCP (200-300 ppb / 12h) upheld fruit firmness, delayed ripening and fruit fresh weight loss.

\section{ACKNOWLEDGMENTS}

The authors thank the National Council of Scientific and Technological Development (CNPq Brazil) and the Coordination for the Improvement of Higher Education Personnel (CAPES - Brazil). 
RESUMO: Neste trabalho avaliou-se o efeito do ácido acetilsalicílico (ASA) e 1-metilciclopropeno (1MCP) no controle da antracnose do mamão (cv Golden). Para isso o Colletotrichum gloeosporioides foi inoculado em frutos superfícialmente desinfestados para depois aplicar-se os compostos. O diâmetro das lesões e as características físico-químicas foram determinadas. Os ensaios foram conduzidos com ASA e 1-MCP visando o controle da antracnose e a manutenção das características físico-químicas do fruto. O efeito do AAS ( $20 \mathrm{mM} ; 20 \mathrm{~min}$ ) na redução do diâmetro da lesão ocorreu quando aplicado antes da inoculação. Frutos tratados com 1-MCP (300 ppb) por 12 horas apresentaram menor diâmetro de lesão que controle. Para a análise físicoquímica, frutos tratados com 1-MCP $(200 ; 300 \mathrm{ppb} ; 12 \mathrm{~h})$ mantiveram a firmeza, o amadurecimento tardio e a perda de massa fresca dos frutos. frutos.

PALAVRAS-CHAVE: Colletotrichum. Controle de doenças. Maturação. Podridão. Qualidade dos

\section{REFERENCES}

ABELES, F. B.; MORGAN, P. W.; SALTVEIT Jr., M. E. Ethylene in plant biology. 2 ed., San Diego, USA: Academic Press, 1997. 413p.

AHMAD, A.; ZAINON, M. A.; ZAINAL, Z. Delayed softening of papaya (Carica papaya L. 'Sekaki') fruit by 1-methylcyclopropene (1-MCP) during ripening at ambient and low temperature storage conditions. Australian Journal of Crop Science, v. 7, n. 6, p. 750-757, 2013. https://trove.nla.gov.au/version/197732102

ALMONEAFY, A. A.; OJAGHIAN, M. R.; SENG-FU, X.; IBRAHIM, M.; GUAN-LIN, X.; YU, S.; WENXIAO, T.; BIN, L. Synergistic effect of acetyl salicylic acid and DL-Beta-aminobutyric acid on biocontrol efficacy of Bacillus strains against tomato bacterial wilt. Tropical Plant Pathology, Brasilia, v. 38, n. 2, p. 102-113, 2013. http://dx.doi.org/10.1590/S1982-56762013000200003

AMARAL, D. D.; MONTEIRO, A. L. R.; SILVA, E. I.; LINS, S. R. O.; OLIVEIRA, S. M. A. Frequency of quiescent fungi and post-harvest alternative management of stem end rot in papaya. Revista Caatinga, Mossoró, v.30, n.3, p.786-793. 2017. https://dx.doi.org/10.1590/1983-21252017v30n327rc

ASMAR, S. A.; ABREU, C. M. P.; LIMA, R. A. Z.; CORRÊA, A. D.; SANTOS, C. D. Firmeza de mamão tratado com 1-MCP em diferentes tempos de exposição. Ciência e Agrotecnologia, Universidade Federal de Lavras, Lavras, v. 34, n. 2, p. 440-444, 2010. http://dx.doi.org/10.1590/S1413-70542010000200024

AYÓN-REYNA, L. E.; GONZÁLEZ-ROBLES, A.; RENDÓN-MALDONADO, J. G.; BÁEZ-FLORES, M. E.; LÓPEZ-LÓPEZ, M. E.; VEGA-GARCÍA, M. O. Application of a hydrothermal-calcium chloride treatment to inhibit postharvest anthracnose development in papaya. Postharvest Biology and Technology, Amsterdam, v.124, p.85-90. 2017. https://doi.org/10.1016/j.postharvbio.2016.10.009

BIZJAK, J.; SLATNAR, A.; STAMPAR, F.; VEBERIC, R. 2012. Changes in quality and biochemical parameters in 'Idared' apples during prolonged shelf life and 1-MCP treatment. Food Science Technology International, v. 18, p. 569-577, 2012. https://doi: 10.1177/1082013212442178

BLANKENSHIP, S. M.; DOLE, J. M. 1-Methylcyclopropene: a review. Postharvest Biology and Technology, Amsterdam, v. 28, n. 1, p. 1-25, 2003. https://doi.org/10.1016/S0925-5214(02)00246-6

BLUM, L. E. B.; AMARANTE, C. V. T.; DEZANET, A.; LIMA, E. B.; NETO, P. H.; ÁVILA, R. D.; SIEGA, V. Postharvest application of phosphites reduces blue mold on 'Fuji' and 'Gala' apples. Revista Brasileira de Fruticultura, Jaboticabal, v. 29, p. 265-268, 2007. http://dx.doi.org/10.1590/S0100-29452007000200015 CAO, S.; ZHENG, Y. Effect of 1-methylcyclopropene on anthracnose rot caused by Colletotrichum acutatum and disease resistance in loquat fruit. Journal of the Science of Food and Agriculture, v. 90, p. 2289-2294, 2010. https://doi.org/10.1002/jsfa.4084 
COUEY, H. M.; ALVAREZ, A. M. 1984. Comparison of hot-water spray and immersion treatments for control of post-harvest decay of papaya. Plant Disease, v. 68, p. 436-437, 1984.

https://www.apsnet.org/publications/PlantDisease/BackIssues/Documents/1984Articles/PlantDisease68n05_43 6.PDF https://doi.org/10.1094/PD-69-436

CRUZ, A. F.; MEDEIROS, N. L.; BENEDET, G. L.; ARAÚJO, M. B.; UESUGI, C. H.; FERREIRA, M. A. S. V.; PEIXOTO, J. R.; BLUM, L. E. B. Control of post-harvest anthracnose infection in guava (Psidium guajava) fruits with phosphites, calcium chloride, acetyl salicylic acid, hot water, and 1-MCP. Horticulture

Environment and Biotechnology, v. 56, n. 3, p. 330-340, 2015. https://doi.org/10.1007/s13580-015-0135-9

DEMARTELAERE, A. C. F.; NASCIMENTO, L. C.; GUIMARÃES, G. H. C.; SILVA, J. A.; LUNA, R. G. Elicitors on the control of anthracnose and post-harvest quality in papaya fruits. Pesquisa Agropecuária Tropical, Goiânia, v.47, n.2, 211-217. 2017. http://dx.doi.org/10.1590/1983-40632016v4745093

DICKMAN, K. B. Part V. Papaya: Anthracnose. In: PLOETZ, R. C.; ZENTMYER, G. A.; NISHIJIMA, W. T.; ROHRBACH, K. G.; OHR, H. D. (Ed.). Compendium of Tropical Fruit Diseases. St Paul, APS Press, 1994. p. 58-59.

DONG, L.; LURIE, S.; ZHOU, H. Effect of 1-methylcyclopropene on ripening of 'Canino' apricots and 'Royal Zee’ plums. Postharvest Biology and Technology, Amsterdam, v. 24, p. 135-145, 2002.

https://doi.org/10.1016/S0925-5214(01)00130-2

FABI, J. P.; CORDENUNSI, B. R.; BARRETO, G. P. M.; MERCADANTE, A. Z.; LAJOLO, F. M.; NASCIMENTO, J. J. R. O. Papaya fruit ripening: response to ethylene and 1-methylcyclopropene (1-MCP). Journal of Agriculture and Food Chemistry, v. 55, p. 6118-6123, 2007. https://pubs.acs.org/doi/pdf/10.1021/jf070903c https://doi.org/10.1021/jf070903c

FERRAZ, D. M. M.; BLUM, L. E. B.; CRUZ, A. F.; UESUGI, C. H.; PEIXOTO, J. R. Reduction of guava anthracnose (Colletotrichum gloeosporioides) by hot water treatments of fruits from organic or conventional system of production. International Journal of Postharvest and Technology Innovation, v. 3, n. 3, p. 272284, 2013. https://doi.org/10.1504/IJPTI.2013.059307

GAMAGAE, S. U.; SIVAKUMAR, D.; WILSON, C., WIJERATMAN, R. S.; WIJESUNDERA, R. L. C. Use of sodium bicarbonate and Candida oleophida to control anthracnose in papaya during storage. Crop

Protection, v. 22, p. 775-779, 2003. https://doi.org/10.1016/S0261-2194(03)00046-2

HOROTAN, A.; OANCEA, A. Effects of fungicide and acetylsalicylic acid treatments on the physiological and enzymatic activity in tomato (Lycopersicon esculentum Mill.). Acta Universitatis Cibiniensis Series E: Food Technology, v. 17, p. 13-26, 2013. https://DOI:10.15835/buasvmcn-hort:10583

JACOMINO, A. P.; BRON, I. U.; KLUGE, R. A. Advance in papaya postharvest technology. In: MARTINS D.S. Papaya Brazil: papaya quality for internal market. Vitória, Incaper, 2003. p. 279-289.

MAHAJAN, P. V.; CALEB, O. J.; SINGH, Z.; WATKINS, C. B.; GEYER, M. Postharvest treatments of fresh produce. Philosophical Transactions Series A, Mathematical, Physical and Engineering Sciences, v. 372: 20130309, 2014. https://DOI: 10.1098/rsta.2013.0309

MANENOI, A.; BAYOGAN, E. R. V.; THUMDEE, S.; PAULL, R. E. Utility of 1-methylcyclopropene as a papaya postharvest treatment. Postharvest Biology and Technology, Amsterdam, v. 44, p. 55-62, 2007. https://doi.org/10.1016/j.postharvbio.2006.11.005

MANDAL, D.; THAMAWIZUALI, Z. R.; HAZARIKA, T. K.; SHUKLA, A. C. Effect of salicylic acid as papaya post-harvest treatment in ambient condition. Environment \& Ecology, v. 35, n. 4C, p. 3149-3153, 2017. https://www.cabdirect.org/cabdirect/FullTextPDF/2018/20183048587.pdf 
MIRSHEKARI, A.; DING, P.; KADIR, J.; GHAZALI, H. M. Effect of hot water dip treatment on postharvest anthracnose of banana var. Berangan. African Journal of Agriculture Research, v. 7, p. 6-10, 2012. https://doi.org/10.5897/AJAR11.056

OHASHI, T. L., FOUKARAKI, S., CORREAA, D. S., FERREIRA, M. D., TERRY, L. Influence of 1methylcyclopropene on the biochemical response and ripening of 'solo' papayas. Revista Brasileira de Fruticultura, Jaboticabal, v. 38, n. 2, e-791. 2016. https://dx.doi.org/10.1590/0100-29452016791

OLIVEIRA, F. E. R.; ABREU, M. P.; ASMAR, S. A.; CORREAA, A. D.; SANTOS, C. D. Firmness of peach 'diamante' treated with 1-MCP. Revista Brasileira de Fruticultura, Jaboticabal, v. 27, n. 3, p. 366-368, 2005. http://dx.doi.org/10.1590/S0100-29452005000300007

PESIS, E.; ACKERMAN, M.; BEN-ARIE, R.; FEYGENBERG, O.; FENG, X.; APELBAUM, A.; GOREN, R.; PRUSKY, D. Ethylene involvement in chilling injury symptoms of avocado during cold storage. Postharvest Biology and Technology, Amsterdam, v. 24, p. 171-181, 2002. https://doi.org/10.1016/S09255214(01)00134-X

PINHEIRO, A. C. M.; VILAS BOAS, E. V. B.; MESQUITA, C. R. Action of 1-methylcyclopropene (1-MCP) on shelf life of 'apple' banana. Revista Brasileira de Fruticultura, Jaboticabal, v. 27, n. 1, p. 25-28, 2005. http://dx.doi.org/10.1590/S0100-29452005000100009

PROMYOU, S.; SUPAPVANICH, S. Effects of salicylic acid immersion on physicochemical quality of Thai papaya fruit 'Kaek Dam' during storage. Acta Horticulture, v. 1111, p. 105-112, 2016. DOI:

10.17660/ActaHortic.2016.1111.16

QIN, G. Z.; TIAN, S. P.; XU, Y.; WAN, Y. K. Enhancement of biocontrol efficacy of antagonistic yeasts by salicylic acid in sweet cherry fruit. Physiological Molecular Plant Pathology, v. 62, p. 147-154, 2003. https://doi.org/10.1016/S0885-5765(03)00046-8

SISLER, E. C.; SEREK, M. Inhibitors of ethylene responses in plants at the receptor level. Physiologia Plantarum, v. 100, n. 3, p. 577-582, 1997. https://doi.org/10.1111/j.1399-3054.1997.tb03063.x

SRIVASTAVA, M. K.; DWIVEDI, V. N. Delayed ripening of banana fruit by salicylic acid. Plant Science, Clare, v. 158, p. 87-96, 2000. https://doi.org/10.1016/S0168-9452(00)00304-6

YIMYONG, S.; DATSENKA, T. U.; HANDA, A. K.; SERAYPHEAP, K. Hot water treatment delays ripening-associated metabolic shift in 'Okrong' mango fruit during storage. Journal of American Society of Horticultural Science, v. 136, n. 6, p. 441-451, 2011. https://doi.org/10.21273/JASHS.136.6.441

YIN, X.; ZHANG, Y.; ZHANG, B.; YANG, S.; SHI, Y.; FERGUSON, I. B.; CHEN, K. Effects of acetylsalicylic acid on kiwifruit ethylene biosynthesis and signaling components. Postharvest Biology and Technology, Amsterdam, v. 83, p. 27-33, 2013. https://doi.org/10.1016/j.postharvbio.2013.03.012

ZAINURI, D.; JOYCE, C.; WEARING, A. H.; COATES, L.; TERRY, L. Effects of phosphonate and salicylic acid treatments on anthracnose disease development and ripening of 'Kensington Pride' mango fruit. Australian Journal of Experimental Agriculture, Collingwood, v. 41: 805-813. 2001. https://doi.org/10.1071/EA99104 